\title{
Out of Pocket Expenditure on Health Service Delivery at a Tertiary Care Women's Hospital: A Descriptive Cross-sectional Study
}

\author{
Puja Gartaula, ${ }^{1}$ Shristi Neupane, ${ }^{1}$ Dip Narayan Thakur, ${ }^{2}$ Raj Kumar Sangroula ${ }^{1}$ \\ 'Department of Public Health, Little Buddha College of Health Sciences, New Baneshwar, Kathmandu, Nepal, ${ }^{2}$ Nepal \\ Public Health Research and Development Center, New Baneshwar, Kathmandu, Nepal.
}

\section{ABSTRACT}

Introduction: Institutional delivery in Nepal is increasing in the past decades and has been the priority program of the government of Nepal. However, due to the hidden costs related to institutional deliveries, the financial burden remains unacceptably high for poor households. The study aimed to find out the major out of pocket expenditure on health service delivery at a tertiary care hospital in Kathmandu, Nepal.

Methods: A descriptive cross-sectional study was carried out at a tertiary care hospital from December 2018 to May 2019. Ethical approval was taken from Nepal Health Research Council (ref. no. 2087) and permission was taken from the hospital. Informed consent was taken from the participants. Convenient sampling was done. A semi-structured questionnaire was used as a tool for the interview. Data was entered into Epidata and analyzed using the Statistical Package of the Social Sciences version 23. Descriptive analysis was done using mean, median, standard deviation, interquartile range, frequency, and percentage.

Results: The median out of pocket expenditure of the participants to maternal delivery was NRs. 11720 (7610-20263). The median expenditure was found highest for food and drinking NRs. 2500 (1500-5550) and transportation NRs. 2150 (1400-4543) respectively.

Conclusions: Indirect expenditures were found to be higher than the direct medical expenditures. Accessibility of the birthing centers and health insurance may reduce the costs related to maternal deliveries.

Keywords: direct; expenditures; health; indirect; institutional delivery.

\section{INTRODUCTION}

The reduction in maternal and child mortality has accelerated in a few decades but the scenario of developing countries is different. ${ }^{1,2}$ The reasons behind this is the lack of access to health services, especially among the poor, where healthcare access often imposes a substantial economic burden. ${ }^{3}$ The constitution of Nepal addresses health as a fundamental right and provides a platform for free basic health care services free of cost. ${ }^{4}$

To expand access to safe deliveries, Nepal has initiated the Safe Delivery Incentive Programme (SDIP) in 2006 focusing on reducing the high costs related to accessing healthcare at childbirth. ${ }^{5}$ Despite free delivery and incentive, hidden costs continue to exist. ${ }^{6}$ Different studies conducted in developing countries have shown that the cost of care during childbirth is a major factor for the utilization of maternal health services. ${ }^{7}$ It is important to assess maternal satisfaction with care in order to make it more responsive and culturally

Correspondence: Ms. Puja Gartaula, Little Buddha College of Health Sciences, New Baneshwar, Kathmandu, Nepal. Email: renuika.gartaula21@gmail.com, Phone: +977-9843290221. 
acceptable, ultimately leading to enhanced utilization and improved outcomes. At a time when global efforts to reduce maternal mortality have been stepped up, maternal satisfaction and its determinants also need to be addressed by developing country governments. This review seeks to identify determinants of women's satisfaction with maternity care in developing countries. Methods: The review followed the methodology of systematic reviews. Public health and social science databases were searched. English articles covering antenatal, intrapartum or postpartum care, for either home or institutional deliveries, reporting maternal satisfaction from developing countries (World Bank list

This study aims to find out the major out of pocket expenditure on health service delivery at Paropkar Maternity and Women's Hospital, Teku, Kathmandu.

\section{METHODS}

A descriptive cross-sectional study was conducted to assess the out of pocket expenditure to maternal deliveries at the Paropkar Maternity and Women's Hospital, Teku from December 2018 to May 2019. Ethical approval was taken from Nepal Health Research Council (Reference no: 2087) and permission was taken from Paropkar Maternity and Women's hospital. Written informed consent was taken from the participants. The caretakers (husbands) of the women who recently delivered babies in Paropkar Maternity and Women's hospital were included in the study. The sample size was calculated by the following formula:

$\mathrm{n}=\mathrm{Z}^{2} \times \mathrm{p} \times(1-\mathrm{p}) / \mathrm{e}^{2}$

$=(1.96)^{2} \times(0.6) \times(0.4) /(0.08)^{2}$

$=144$

Where,

$\mathrm{n}=$ sample size

$\mathrm{Z}=1.96$ at $95 \%$ Confidence Interval $(\mathrm{Cl})$

$\mathrm{p}=$ prevalence of out of pocket expenditure, $60 \%{ }^{8}$

$\mathrm{e}=$ margin of error

Including a non-response of $15 \%$, the final sample size was 165 . The convenient sampling technique was used to select the participants for the study.

The variables under study were socio-demographic and accessibility variables like age, sex, religion, ethnicity, education, occupation, age at first pregnancy, number of children, mode of delivery, and the time taken to reach a health facility. Cost related variables included (i) Direct medical costs: medicines and supplies, laboratory and diagnostic services, blood transfusion (expenditure for arranging blood), doctors fee if applicable; (ii) Indirect medical expenditures like transportation cost for seeking services, expenses on food during the stay in the facility, loss of wages and other category includes all the expenditure that the caregiver could not classify under the specific categories.

Pretested semi-structured Questionnaire was used as a tool for interviews. Face to face interview was used as a technique to find out the major out of pocket expenditure to maternal deliveries. Completeness and consistency of the filled questionnaires were ensured on the same day of the data collection.

Collected data were edited manually to check completeness and accuracy and entered in Epi data. Data analysis was done in IBM Statistical Package for Social Science (SPSS) 23. Descriptive analysis was done using mean, median, frequency, percentage, interquartile range, and standard deviation.

\section{RESULTS}

In the study, the median cost for medicine was NRs. 1700 (1300-4150) and for blood transfusion was NRs. 535 ( 0 - 567). The median cost for transportation, food, and other (communication, laundry, etc.) was NRs. 2150 (1400-4543), Nrs. 2500 (1500-5550), and Nrs. 500 (350-850) respectively. The median loss of wages of the husband was NRs. 2000 (1600-2666). The total median out-of-pocket health expenditure was NRs. 11720 (7610 - 20263) (Table 1).

\begin{tabular}{|c|c|c|}
\hline Health Expenditure & $\begin{array}{l}\text { Mean } \pm \text { SD } \\
\text { (NRs.) }\end{array}$ & $\begin{array}{l}\text { Median (IQR) } \\
\text { (NRs.) }\end{array}$ \\
\hline \multicolumn{3}{|l|}{ Direct Expenditure } \\
\hline Medicines & $3684 \pm 4891$ & $\begin{array}{l}1700(1300- \\
4150)\end{array}$ \\
\hline Blood transfusion & $502 \pm 620$ & $535(0-567)$ \\
\hline $\begin{array}{l}\text { Total Direct } \\
\text { Expenditure }\end{array}$ & $4186 \pm 5250$ & $\begin{array}{l}2035(1500- \\
4920)\end{array}$ \\
\hline \multicolumn{3}{|l|}{$\begin{array}{l}\text { Indirect } \\
\text { Expenditure }\end{array}$} \\
\hline Transportation & $4137 \pm 5044$ & $\begin{array}{l}2150(1400- \\
4543)\end{array}$ \\
\hline Food & $4698 \pm 5926$ & $\begin{array}{l}2500(1500- \\
5550)\end{array}$ \\
\hline Others & $642 \pm 387$ & $\begin{array}{l}500 \\
(350-850)\end{array}$ \\
\hline $\begin{array}{l}\text { Loss of wages } \\
\text { of attendants } \\
\text { (husbands) }\end{array}$ & $2534 \pm 2354$ & $\begin{array}{l}2000 \\
(1600-2666)\end{array}$ \\
\hline $\begin{array}{l}\text { Loss of wages of } \\
\text { recently delivered } \\
\text { women }(n=28)\end{array}$ & $218 \pm 495$ & - \\
\hline $\begin{array}{l}\text { Total Indirect } \\
\text { Expenditure }\end{array}$ & $12230 \pm 9986$ & $\begin{array}{l}8750 \\
(5650-14600)\end{array}$ \\
\hline Total Expenditure & $16418 \pm 13508$ & $\begin{array}{l}11720 \\
(7610-20263)\end{array}$ \\
\hline
\end{tabular}


The age at marriage for $95(57.6 \%)$ respondents was below 20 years of age with a median of 20 years. Similarly, $100(60.6 \%)$ women were pregnant at the age of 20 years or more with a median of 22 years. One hundred and forty-eight (89.7\%) respondents had two children or less. Regarding the mode of recent delivery, $108(65.5 \%)$ had a normal mode of delivery and $138(83.6 \%)$ stayed at the hospital for 5 or fewer days. It took less than one hour to reach the hospital for $123(74.5 \%)$ respondents (Table 2 ).

\begin{tabular}{|lc|}
\hline \multicolumn{2}{|l|}{ Table 2. Maternal health-related characteristics of the } \\
participants. & \\
\hline Characteristics & Frequency $\mathrm{n}(\%)$ \\
Age at marriage & $95(57.6)$ \\
Less than 20 & $70(42.4)$ \\
More than 20 & $65(39.4)$ \\
Age at first pregnancy & $100(60.6)$ \\
Less than 20 & $148(89.7)$ \\
More than 20 & $17(10.3)$ \\
Total no. of childbirth & \\
Less than 2 & $108(65.5)$ \\
More than 2 & $57(34.5)$ \\
Mode of delivery & \\
Normal delivery & $138(83.6)$ \\
C- Section & $27(16.4)$ \\
Length of stay & \\
$\leq 5$ days & $123(74.5)$ \\
$>5$ days & $42(25.5)$ \\
Distance &
\end{tabular}

One hundred and fifty-five (93.9\%) families had a male head and 125 (75.8\%) respondents were Hindu. Regarding the ethnicity of the respondents, 87 (52.7\%) were Janajati, 62 (37.6\%) were Brahmin/Chhetri and 16 (9.7\%) were Dalit/Madhesi. For 57 (34.5\%) respondents, their husbands' occupation was agriculture followed by labor for $48(29.1 \%)$. Whereas, most of the women were housewives, i.e. 137 (83.0\%). Seventy-six (46.1\%) participants belonged to a nuclear family, and 48 $(29.1 \%)$ belonged to a joint family. One hundred and forty-seven (89.1\%) delivered women were literate and $51(33.7 \%)$ had some secondary level of education. One hundred and nineteen (72.1\%) had a monthly income less than NRs. 25000 and the median family income was NRs. 20000. One hundred and three (63.0\%) had family members less than five (Table 3 ).

\begin{tabular}{|ll|}
\hline $\begin{array}{l}\text { Table 3. Socio-demographic characteristics of the } \\
\text { participants. }\end{array}$ \\
\hline Characteristics & Frequency n (\%) \\
\hline Head of Family & $155(93.9)$ \\
Male & $10(6.1)$ \\
Female & \\
Religion of Family &
\end{tabular}

\begin{tabular}{|c|c|}
\hline Characteristics & Frequency n (\%) \\
\hline Hindu & $125(75.8)$ \\
\hline Buddhist & $31(18.8)$ \\
\hline Christian & $9(5.5)$ \\
\hline \multicolumn{2}{|l|}{ Ethnicity of Family } \\
\hline Brahmin/Chettri & $62(37.6)$ \\
\hline Janjati & $87(52.7)$ \\
\hline Dalit/ Madhesi & $16(9.7)$ \\
\hline \multicolumn{2}{|l|}{ Father's Education } \\
\hline Literate & $151(91.5)$ \\
\hline Illiterate & $14(8.5)$ \\
\hline \multicolumn{2}{|l|}{$\begin{array}{l}\text { Level of Education of Father } \\
(n=151)\end{array}$} \\
\hline Primary & $20(13.25)$ \\
\hline Lower secondary & $22(14.57)$ \\
\hline Secondary & $51(33.77)$ \\
\hline Higher Secondary and more & $58(38.41)$ \\
\hline \multicolumn{2}{|l|}{ Mother's Education } \\
\hline Literate & $147(89.1)$ \\
\hline Illiterate & $18(10.9)$ \\
\hline \multicolumn{2}{|l|}{$\begin{array}{l}\text { Level of Education of } \\
\text { Mother }(n=147)\end{array}$} \\
\hline Primary & $29(19.7)$ \\
\hline Lower secondary & $79(53.7)$ \\
\hline Secondary & $26(17.7)$ \\
\hline Higher secondary or more & $13(8.8)$ \\
\hline \multicolumn{2}{|l|}{ Occupation of Husband } \\
\hline Agriculture & $57(34.5)$ \\
\hline Service & $28(17.0)$ \\
\hline Labor & $48(29.1)$ \\
\hline Foreign Employment & $13(7.9)$ \\
\hline Business & $19(11.5)$ \\
\hline \multicolumn{2}{|l|}{ Occupation of Mother } \\
\hline Housekeeping & $137(83.0)$ \\
\hline Service/Labor & $41(17)$ \\
\hline \multicolumn{2}{|l|}{ Types of Family } \\
\hline Nuclear Family & $76(46.1)$ \\
\hline Joint Family & $48(29.1)$ \\
\hline Extended Family & $41(24.8)$ \\
\hline \multicolumn{2}{|l|}{ Income of Family } \\
\hline Less than 25000 & $119(72.1)$ \\
\hline More than 25000 & $46(27.9)$ \\
\hline
\end{tabular}

\section{DISCUSSION}

Out-of-pocket expenditure in health may harm the household economy of people, especially in developing countries. ${ }^{9} \mathrm{Nepal}$ still has a high proportion of out-of-pocket health payment and a limited riskpooling mechanism. Out-of-pocket payment for the healthcare services could result in catastrophic health expenditure ( $\mathrm{CHE})$. This study was conducted to identify out of pocket expenditure in delivery care at Paropakar Hospital, Kathmandu. 
In Nepal, out of pocket expenditure has increased by more than $30 \%$ during the last 15 years, with the share of OOPS in consumption expenditure increasing from $3.4 \%$ in $1995-1996$ to $4.5 \%$ in $2010-2011 .{ }^{10}$ Many people in Nepal are not able to afford twoway transportation costs despite transport incentives provided by the government for institutional delivery. This study showed median transportation cost was NRs. 2150. The median cost for food and drinking was highest among the costs with NRs. 2500. In western Nepal, about $53.07 \%$ of total expenditure was food and drinking and contributed the highest among all expenditure. ${ }^{11}$ A study conducted in Nigeria showed that expenditure after child care was higher for food. ${ }^{12}$ Similarly, a major share in out-of-pocket expenditure in India was Tips and the median value of OOPE was 320 INRs. $^{3}$ A study conducted in tertiary hospitals of Bangladesh showed that costs for medicine, transportation, and food were the first, second, and third major expenditures respectively..$^{13}$ The findings from this study suggest that hospital attendees should also be focused by the government as expenditure is higher for food and drinking. In this study, the median loss of wages of the attendants was NRs. 2000 and the median loss of wages for the recently delivered women were negligible as many were housewives but a study conducted in the Western part of Nepal had a

\section{REFERENCES}

1. WHO. Maternal mortality [Internet]. Geneva: World Health Organization; 2019 Sep 19 [cited 2019 Jun 2]. Available from: https://www.who.int/en/news-room/fact-sheets/detail/ maternal-mortality. [Full Text]

2. WHO. Children: improving survival and well-being [Internet]. Geneva: World Health Organization; 2020 Sep 8 [cited 2020 Oct 16]. Available from: https://www. who.int/news-room/fact-sheets/detail/children-reducing-mortality. [․ull Text]

3. Issac A, Chatterjee S, Srivastava A, Bhattacharyya S. Out of pocket expenditure to deliver at public health facilities in India: a cross sectional analysis. Reprod Health. 2016 Aug 24;13(1):99. [uuMed | Full Text | DOI]

4. Mishra SR, Khanal P, Karki DK, Kallestrup P, Enemark U. National health insurance policy in Nepal: Challenges for implementation. Glob Health Action. 2015;8(1). doi:10.3402/ gha.v8.28763. [PubMed | Full Text | DOI]

5. DoHS. Annual Report 2070/71 (2013/14) [Internet]. Kathmandu: Department of Health Services, Ministry of Health and Population; 2014 [cited 2019 Jun 2]. 425 p. Available from: http://dohs.gov.np/wp-content/ uploads/2014/04/Annual_Report_2070_71.pdf. [Full Text]

6. Leone T, James KS, Padmadas SS. The burden of maternal health care expenditure in India: Multilevel analysis of national data. Matern Child Health J. 2013;17(9):1622-30. [PubMed $|\underline{\text { Full Text }}| \underline{\text { DOI] }}$ higher loss of wages of both the husbands and wives. ${ }^{14}$ This may be due to the different length of stay at the hospital. The study showed median total expenditure on delivery was NRs. 11720 which is more than $50 \%$ of the total monthly income of the family. While in India the median expenditure in delivery was only INRs. 700.3 But the median expenditure was much lower than a study conducted in tertiary hospitals of Western Nepal. ${ }^{11}$ The different findings in total expenditure may be due to less cesarean section which decreases the length of stay and distance of hospital from home.

\section{CONCLUSIONS}

In this study, the expenditure on basic needs like food and drinking was higher among other expenditures. Expenditure on transportation contributed secondly to the total delivery related expenditure. These costs may be barriers to hospital delivery for families with the poor socio-economic condition. Increasing coverage of health insurance and accessibility of birthing centers may reduce the costs of pregnant women attending healthcare for delivery.

\section{Conflict of Interest: None.}

7. Srivastava A, Avan BI, Rajbangshi P, Bhattacharyya S. Determinants of women's satisfaction with maternal health care: A review of literature from developing countries. BMC Pregnancy Childbirth. 2015 Apr 18;15(1).97. [릴ed | Full $\underline{\text { Text }} \mid \underline{\mathrm{DOI}}]$

8. WHO. Health financing profile 2017: Nepal [Internet]. Geneva: World Health Organization; 2017 [cited 2019 Jun 2]. Available from: https://apps.who.int/iris/ handle/10665/259643. [Full Text]

9. Ghimire M, Ayer R, Kondo M. Cumulative incidence, distribution, and determinants of catastrophic health expenditure in Nepal: Results from the living standards survey. Int J Equity Health. 2018 Feb 14;17(1):23. [PubMed | Full Text | DOI]

10. Gupta I, Chowdhury S. Correlates of out-of-pocket spending on health in Nepal: implications for policy. WHO South East

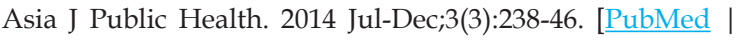
Full Text | DOI]

11. Acharya J, Kaehler N, Marahatta SB, Mishra SR, Subedi S, Adhikari B. Hidden costs of hospital based delivery from two tertiary hospitals in western Nepal. PLoS One. 2016 Jun 16;11(6):e0157746. [라Med | Full Text | DOI]

12. Aisha AN. Expenditure on Emergency Obstetric Care in a Federal Tertiary Institution in Nigeria. J Women's Heal Care. 2013;2:4. [Full Text | DOI]

13. Nahar S, Costello A. The hidden cost of 'free' maternity care in Dhaka, Bangladesh. Health Policy Plan. 199

This work is licensed under a Creative Commons Attribution 4.0 International License. The images or other third party material in this article are included in the article's Creative Commons license, unless indicated otherwise in the credit line; if the material is not included under the Creative Commons license, users will need to obtain permission from the license holder to reproduce the material. To view a copy of this license, visit http://creativecommons.org/licenses/by/4.0/ 